\title{
Study of the System of Scientific and Scientific-Technical Activities of Agrarian and Economic Universities
}

\author{
https://doi.org/10.3991/ijep.v11i3.20541 \\ Milena Tsvetkova $(\bowtie)$ \\ Sofia University, Sofia, Bulgaria \\ tsvetkovamileerambler.ru \\ Zhenisbek Suleimenov \\ Kazakh National Agrarian University, Almaty, Kazakhstan \\ Larisa Kondratenko \\ Kuban State Agrarian University I.T. Trubilin, Krasnodar, Russia \\ Diana Stepanova \\ Plekhanov Russian University of Economics, Moscow, Russia
}

\begin{abstract}
Currently it is relevant to find effective ways to train scientific personnel and comprehensively study systems of scientific and scientifictechnical activities of universities. The purpose of this study is to compare scientific and scientific-technical activities of agrarian and economic universities in Russia, Kazakhstan and Bulgaria, where personnel is trained for one of the leading industries in these countries. An anonymous online survey based on a specially designed questionnaire was conducted; it involved 162 respondents from the countries above - scientific and pedagogical staff of agrarian and economic universities. The results of the present study, in comparison with the data of scientific literature, allow one to assert that the common global problems in universities are unstable funding and a decline in the prestige of a scientific career. The latter makes it difficult to attract young people to science, leads to aging of scientific personnel, dissatisfaction with work, and the risk of professional burnout. At the same time, fierce competition imposes increased requirements on the quality of universities' scientific products and their promotion in the market of research and scientific-pedagogical services. As a result of the research, general and distinctive features of scientific and scientific-technical activities of agrarian and economic universities of Russia, Kazakhstan, and Bulgaria have been identified. Based on the empirical data obtained and their comparison with the results of an analytical review of scientific literature, a generalized universal model of the system of universities' scientific and scientifictechnical activities has been created, which will optimize the reform process and contribute to the development of research potential.
\end{abstract}

Keywords - Higher education; agrarian and economic universities; higher educational institutions; innovation; international cooperation in the field of science; scientific and scientific-technical activities; scientific information; systemic approach 


\section{Introduction}

Higher educational institutions, regardless of industry affiliation and the type of ownership, combine pedagogical, scientific, and scientific-technical activities integrating, thus, science and education [1-3]. The concentration of highly qualified scientific and pedagogical personnel combined with the availability of research laboratories, opportunities for conducting experiments and other resources, ensure significant intellectual, scientific, and scientific-technical potential of higher educational institutions and determine their competitiveness in the educational services market and in the scientific environment $[1,2]$. However, in practice, in the process of organization of scientific and scientific-technical activities of higher educational institutions a number of problems and limitations arise, associated, primarily, with a shortage of financial and human resources [4], which is a significant obstacle for the development of a research base, the renewal of outdated equipment, and attracting young specialists to science. Researchers link the fall of popularity and prestige of a scientific career in recent years, primarily, due to the uncompetitive salary level of scientific and pedagogical workers due to unfocused, contradictory and underdeveloped scientific, technological and innovation state policy [4]. At the same time, low wages, outdated material and technical base (which does not provide an adequate level of research), and increased requirements for scientific products' quality contribute to professional burnout and the outflow of old experienced specialists from the scientific field and a decrease in the motivation of young specialists to engage in scientific research $[5,6]$. In addition, in the post-Soviet world, there is a transition from the old commandadministrative system of management to modern democratic forms of management, which implies that universities gain independence in managing scientific, scientifictechnical activities and finding the necessary investments for their development [7-9]. At the same time, scientific and scientific-technical activities of universities in different countries are characterized by the presence of general patterns and trends of development and specific features that emerge in the process of implementing innovative changes. This multi-vector requires careful study to develop an optimal way to improve scientific potential, develop fundamental and applied university science, as well as find effective ways to educate scientific personnel. In this context, it seems relevant to comprehensively study the systems of scientific and scientific-technical activities of universities. Thus, the object of this study can be defined as the process of research activities of higher educational institutions, the study of which on the basis of a systemic approach involves the choice of the system of scientific and scientifictechnical activities of universities as the research subject.

Taking into account the fact that this activity is primarily regulated by legislation and largely depends on the priority of science at the state level, the purpose of the study is to compare the systems of scientific and scientific-technical activities of agrarian and economic universities in Russia, Kazakhstan, and Bulgaria. Agrarian and economic universities have been chosen due to the fact that this industry is one of the leading in all three countries, which, accordingly, is a factor that determines the priority of the development of higher education and science in this direction. Their comparison is of interest for choosing the most optimal ways for the future development 
of university science and for identifying general patterns of the formation of scientific and scientific-technical potential in the higher education system as a whole.

In accordance with the above, the research objectives have been defined:

1. To study scientific publications on the research topic

2. To conduct a comparative analysis of the systems of scientific and scientifictechnical activities of agrarian and economic universities of Russia, Kazakhstan, and Bulgaria and assess their effectiveness

3. To identify general patterns and differences of the systems of scientific and scientific-technical activities of universities and outline possible optimization solutions

The research hypothesis consists in the assumption that scientific and scientifictechnical activities of agricultural and economic universities in Russia, Kazakhstan, and Bulgaria have both specific differences and common features and patterns of development. The identification of the latter will optimize the process of reforming university science and will contribute to the development of research potential of universities in the agricultural and economic sector and the higher education system as a whole.

\section{Literature Review}

\subsection{Features of scientific and scientific-technical activities of universities}

Scientific (research) activity is aimed at gaining and applying new knowledge, including fundamental, applied, and experimental developments. It should be pointed out that scientific and technical activities are defined as part of research activity aimed at gaining and applying new knowledge to solve technological, engineering, economic, social, humanitarian, and other problems, in order to ensure the operation of science, technology, and production as a single system. At the same time, at the heart of modern scientific activity is an innovative process aimed at creating and commercializing new knowledge in the form of scientific and technical products. The process of integrating science, education and innovation is viewed by researchers as a major contributor to the development of the economy and society [10], which becomes the basis for the natural integration of higher education with enterprises. The actual problem today is the construction of a knowledge economy based on high technologies, scientific and industrial potential, and intellectual property [10]. The scientific activity of the university (Fig. 1) is closely related to the educational process. 


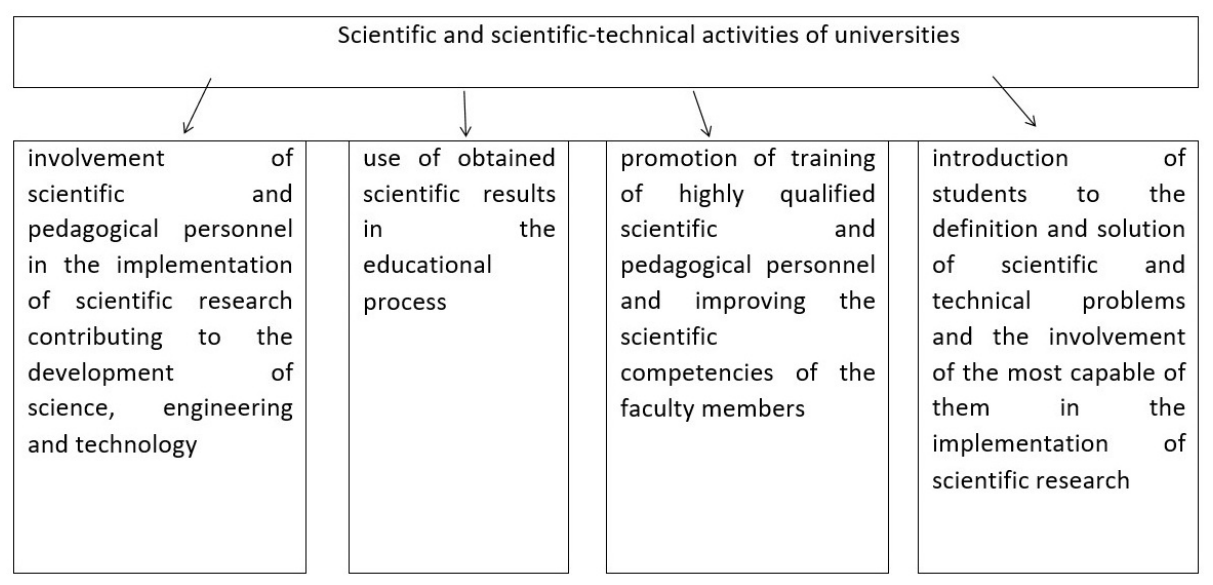

Fig. 1. Features of scientific and scientific-technical activities of universities

Researchers identify such common features of the scientific and scientific-technical activities of universities, such as: the impossibility of formalizing and describing the process of scientific research; the importance of the leader's role; the lack of connection between the contribution of the researcher and the research result; high dependence of research on the volume and nature of funding; the presence of an educational component in the research activities of the university; human and information resources as the key values of research structures. At the same time, the tasks of scientific and scientific-technical activities of a modern university are, in particular, the integration of scientific, educational, and production activities, the development of strategic research directions and thematic research plans, the maintenance and development of the research, information, and computing facilities, as well as activities aimed at popularizing science and giving scientific and methodological assistance to the organizations of all levels and types of ownership in their practical application of the research results and university developments [1] (Fig. 2). 


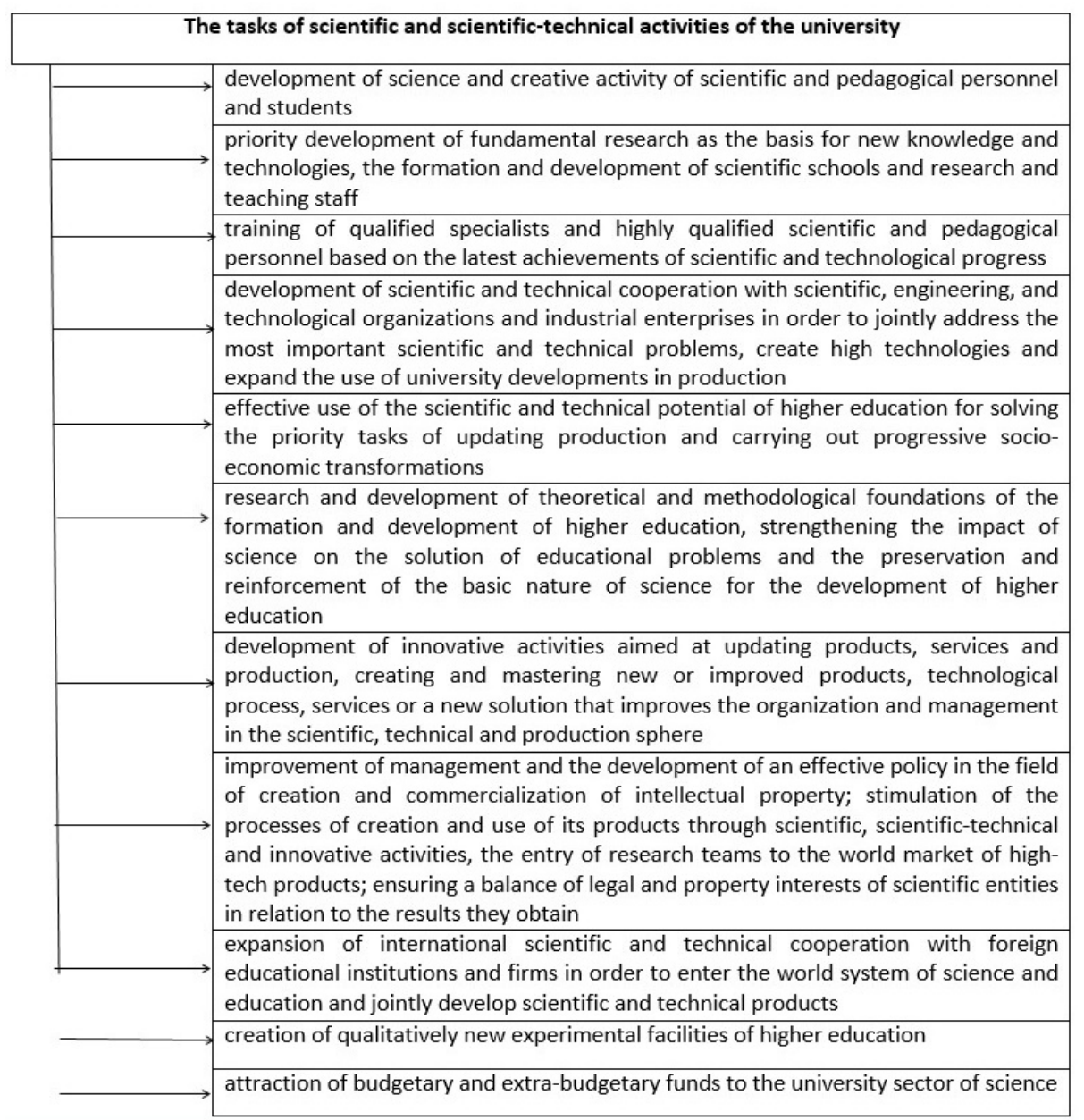

Fig. 2. Basic tasks of scientific and scientific-technical activities of universities

The researchers emphasize that the process of organizing the scientific and scientific-technical activities of a university should be based on ensuring the following components:

- The unity of scientific and educational processes and their focus on the economic, social and spiritual development of society.

- Concentration of resources in priority research areas.

- Competitive principles of the formation of thematic plans of universities, scientifictechnical and innovative programs while ensuring transparency.

- The optimal combination of state order for research activities and their management in the university.

- The development of scientific and technical creativity in students and young professionals. 
- Support for leading scientists, research teams, scientific and scientific-pedagogical schools capable of providing an advanced level of education and scientific research.

- The development of various forms of the organization of research activities at the university.

- The focus of research teams on performing a complete cycle of research and development to create finished products.

- Support for entrepreneurship activities in the scientific and technical sphere.

- The integration into the international scientific and educational community [3].

\subsection{The role of national systems of scientific and technical information in the development of university science}

It should be noted that education can be viewed both as a process and as a result of learning; at the same time, it is a determining factor in people's lives, which renews and increases the intellectual, spiritual, and economic potential of society.

Higher education is aimed at training highly qualified specialists who possess relevant competencies, scientific knowledge and practical skills. The process of obtaining education at universities is based on the development of cognitive abilities and creative potential of an individual, ensuring his/her active and constructive social activity through fundamental scientific, general cultural and special training [11]. The most important means of achieving sustainable economic growth of any state, its strategic and tactical goals, is the formation and implementation of innovative state policy, aimed, first of all, at increasing the role of science and technology. Expansion of international cooperation and improvement of information exchange in the field of scientific, scientific-technical research is ensured thanks to national systems of scientific and technical information, the development of which is the basis for the integration of states into the global information space. In this regard, the issue of creating a specialized electronic interdepartmental information and analytical system is considered, which on a global scale would cover management structures, ministries, academies, scientific foundations, development institutions, research institutes, and universities involved in promising areas of research and possessing significant scientific potential [12]. In the current digital economy development, when economic growth depends on knowledge, competencies, and innovative thinking, the tasks of expanding the interaction of education and science are becoming strategic priorities and the guarantee of the competitiveness of each university, regardless of its form of ownership and industry. Study of these sources of scientific literature on the formation and development of systems of scientific and scientific-technical activities of the Russian Federation, the peculiarities of the relationship between education and research, has confirmed the relevance of the formation and development of the systems of scientific and scientifictechnical activities of universities that integrate education, science and production according to international standards [13]. The importance of psycho-emotional support for young scientists in the process of conducting scientific research and writing dissertations is emphasized, for which it is necessary to ensure both their participation in scientific communities and direct interaction with the scientific advisor, which is a 
key feature of university science [14]. The current stage in the development of society in scientific literature is called the Fourth Industrial Revolution. As companies are increasingly seeking to use new and emerging technologies to achieve greater production and consumption efficiency, enter new markets and ensure competitiveness on a global scale. Accordingly, the professional competence of a specialist is measured in this context, first of all, by his/her ability to think critically, his/her ability to creatively solve complex problems, possess cognitive flexibility and skills of effective industrial communication, as well as foreign languages. Unfortunately, training programs are often lag behind the labor market demand, lacking practical orientation, which makes the development of the necessary competencies ineffective and becomes the reason for the poor preparedness of school graduates for the process of obtaining higher education, their inability to establish the relationship between practical professional activity and the need for scientific research. A systematic approach to the development of university science, through a combination of theory and practice, allows students to form scientific thinking, master the methodology of scientific research [15].

\subsection{Criteria for assessing the effectiveness of scientific, scientific-technical activities of universities and their importance for the educational process}

In recent years, there has been an increasing interest in measuring the effectiveness of university education, especially in connection with the expansion of the university system. Among the most important assessment criteria of university education are both the characteristics of students and funding of research, which become primary material for teaching and providing research services [16]. Therefore, the scientific activity of universities is one of the priority areas of their development, which is of particular importance in modern conditions of tough competition in the market for the provision of educational and research services. In this regard, it is quite logical that the development of scientific potential of higher educational institutions directly correlates with the professional development of teachers, their self-efficacy and job satisfaction [6]. However, in this area there are problems and risks, related to instability of economic processes, the outflow of young professionals and highly qualified personnel abroad or to more highly paid sectors of the economy, the decline in the prestige of scientific and scientific-pedagogical activities. Therefore, the development of university science should be considered as one of the priority strategic goals of a state [28]. Monitoring scientific and scientific-technical university activities is a means to determine educational process effectiveness, to identify the factors influencing it, its shortcomings and problems. Besides, the obtained results can be used to form an information base to optimize the management of scientific and scientific-technical activities. At the same time, approaches to the analysis of this activity of university should be based on the principle of consistency and be aimed at assessing the criteria and indicators of safety, efficiency and effectiveness of performing educational and research tasks. The following indicators are used as criteria for the scientific, scientific-technical activities of universities: the quantitative and qualification composition of scientific personnel; availability of a modern research base; the quality of scien- 
tific, scientific-technical results. These indicators are determined using expert judgment, taking into account the level of publication activity, the main international scientometric indicators, as well as the activity of raising funds and the amount of funding [17]. There are such groups of indicators that reflect the most important areas of scientific activity of the university, such as: conducting scientific research; training highly qualified scientific personnel; ensuring the creative activity of participants in the educational process; using the obtained scientific results in the educational process [17]. Possession of advanced scientific technologies today is the basis for ensuring a high living standard of the population and a criterion for the development of a state, an indicator of its international status. There is a rating system that evaluates the work of teachers, departments and faculties and provides automated monitoring of the scientific and educational activities of universities. This system is closely linked to accreditation indicators, provides a comprehensive assessment and encourages creative teaching and research activities of employees. At the same time, scientometric indicators include dissertations (doctoral dissertations, dissertation management, refutation, and review), publications (scientometric publications, monographs, collections of scientific papers and their editing), patent licensing activities, participation in exhibitions and conferences, organization of research activities of students [29].

To obtain a holistic view of the state of the system of scientific, scientific-technical activities of a university, it is required to monitor these indicators for at least three years, which is the basis for ensuring the adoption of informed management decisions on the further development of university science. However, these indicators, as follows from scientific literature sources, are also recommended to be applied in case of need for a quick assessment of university's scientific, scientific-technical activities [17]. To assess the effectiveness and prospects of scientific, scientific-technical activities of a university one must also have criteria for assessing the quality of individual research in the educational process [18]. It has been proven that the involvement of first-year students in scientific research contributes to their abilities to self-regulate learning, develops skills of independent work, critical thinking and a creative approach to solving professional problems [19]. Within the framework of evidencebased education, the results of randomized controlled trials and their meta-analysis are accepted as reliable evidence of effectiveness; however, statements about their representativeness, as a rule, are not based on convincing evidence [20]. Due to the fact that one of the essential problems of higher education is to ensure the relationship between science and practice, it is necessary to direct research efforts of university science towards forecasting its effectiveness. Wherein it should be borne in mind that randomized controlled trials in the field of evidence-based educational policy and practice, although they can serve as confirmation of causal relationships, however, are not a sufficient basis for predicting the effectiveness of scientific, scientific-technical activities, which makes it necessary to search for more adequate methods of obtaining information, such as data on the implementation. At the same time, planning and forecasting should be carried out in a close relationship between teaching and research ensuring the interaction of theory and practice [21]. Science in the education system is characterized by its scale and diversity possessing significant intellectual resources [22]. Modern educational product is a synthesis of the acquisition of knowledge, the 
formation of skills and attitudes, the assimilation of value orientations, which together constitute the professional competence of a university graduate [7]. Not only university leaders and academic staff, but also politicians and research sponsors are considering partnerships between science and practice as a promising approach, conducive to expanding the role of research in improving the educational process [23]. Thus, the effectiveness of university education is ensured by the relationship between science and practice based on the evidence base for the effectiveness of scientific and pedagogical activities, which is a criterion for achieving successful results and is determined, first of all, by the competitiveness of the educational institution and its graduates [24]. One of the features of current university curricula is their dependence on commercial companies selling digital learning products, where individual economic benefits of higher education obtained by students are determined by the competencies they acquire. At the same time, the development of university curricula is significantly influenced by teaching experience of employees, their awareness of the goals of the educational institution, what determines access to education and maintaining its quality, contributing to the aggravation of the gap between universities in relation to the quality of educational services [9].

\subsection{Vectors of development of scientific, scientific-technical activities of universities in the post-soviet space and in the global world}

The development of educational technologies today is aimed at promoting personalized learning [5]. At the same time, the system of scientific, scientific-technical research in universities should be aimed at the formation in students of both theoretical and value foundations [26], scientific thinking and the ability to identify and solve problems. The latter positively affects academic performance and is a convincing argument in favor of the development of the system of university science as a factor contributing to the development of critical thinking and independent work skills of students [25]. Among educational goals, there is an increasing focus on the formation of critical reflection, primarily, in the social sciences, where it is associated with the personal, interpersonal and socio-structural dimension. The system of scientific and scientific-technical research in higher educational institutions should be aimed at the formulation of the value and theoretical foundations that underlie the conceptualization of reflection both in research and in practice [26]. The organization of researchand project-based learning in higher educational institutions facilitates the early identification and training of raising scientists by engaging students in independent research activities. Problem-based learning helps educators and students systematically conduct practical research integrated into the curriculum. At the same time, teachers help students identify research topics and solve problems; they find optimal approaches to teaching each student and manage the course content as a whole [27]. The reform of educational and scientific activities, especially in the post-Soviet space, is aimed at expanding the freedom of scientific creativity, information exchange, and international cooperation. However, inadequate funding for research and development does not ensure timely renewal of research facilities and creates difficulties for the state governance of science. Scientific personnel is aging and scientific activity is 
becoming less prestigious and attractive to talented youth, which raises the question of a radical reorganization and attracting more funding sources, as well as more effective use of the results of scientific research in the economy. Considering the fact that science is an effective national resource and universities have significant scientific and technical potential, the reform should include the development of the methodology of scientific and innovative policy, intellectual labor market forecast, as well as information, theoretical developments and applied research as scientific-technical products, and, accordingly, the qualitative transformation of the scientific and technical potential of higher education. The conceptual foundations of the development of university science are based on the principle of the unity of scientific and educational processes in their close connection with the economic, social, and spiritual development of society. At the same time, the main vector of reforms is the development of a variety of forms of organization of research work and, in general, the system of scientific and scientific-technical research in universities, aimed at achieving world level of scientific research and the integration of university science into the global system of scientific and technical cooperation. The system of higher education should facilitate the search for and training of talented youth and provide training for scientific elite while being supported by the ministries and the state.

The effectiveness of the development of the education system is determined by the scientific and research activities of universities [30]. At the same time, a specific feature of the scientific and technical creativity of students is the unity of scientific and pedagogical goals. A combination of scientific, technical and entrepreneurial activities of students, as well as the development of relations in the system of higher education, science and production ensure the development, creation and subsequent mass application of new technologies, products and cultural phenomena based on the formation of an innovative personality as a subject of the modernization process. The model of creative activity of students in university education includes interdisciplinary coursework, laboratory research workshops, research assignments completed in the period of internship, diploma projects and scientific studies, as well as various forms of scientific inquiry outside the curriculum, such as a scientific community or participation in the activities of small innovative enterprises [30]. In order to support and encourage research in the European Research Area (ERA), the European Union Framework Programs have been established [31]. In this new era of teaching, educators must provide students with flexibility to create their own learning experience. They need long-term plans as universities are not expected to return to the methods of instruction used before the quarantine. The future offers many opportunities, including greater use of learning analytics, greater control over the pace of learning, recorded lectures, greater participation, and greater access to education. Technology will play a vital role in each of them [32]. The final eighth program, Horizon 2020, ended the last year; however, the projects accepted for funding in 2019-2020 will be continued within the next 3-5 years after its completion [8]. The development of national systems of scientific and technical information and the entry into the international system of scientific research are associated with the need for information support for innovative activities [33]. Despite the fact that final examinations do not currently include scientific subjects as compulsory ones, their introduction is being discussed as 
it is expected that this will increase the motivation of students to study the subject and improve their knowledge; in addition, the majority of students and teachers consider scientific knowledge to be important, although the index of its popularity has recently remained low [34]. Participation of students in scientific research, projects, and presentations contributes to a deeper knowledge of the studied subjects [35]. The presence of a university research base allows the use of a problem teaching method that promotes the assimilation of complex educational material due to the connection between theory and practice [36]. There is a need to transform teaching in higher education towards its practical orientation in order to motivate students, engage them in research, and thereby contribute to their academic performance and better mastery of professional competencies. Flipped Learning - From Practice to Theory - is an interactive and intensive approach that is used to support learning and maximize student-teacher interaction to reinforce the knowledge and skills acquired [37]. The organization of conferences, seminars, lectures and discussions, where the main speakers are experienced specialists and scientists, contributes to the formation of the necessary professional competencies in students, which, along with the assimilation of the norms of professional ethics, contributes to ensuring future social progress and prosperity [34]. The prospective development of university science should be based on the principle of corporate social responsibility, which plays a significant role in human resource management contributing to increased productivity, job satisfaction, and cooperation [38]. Both education providers and society as a whole are interested in such a level of development of the scientific and pedagogical process in universities, which will ensure high confidence in the education system both at the national and international, global levels. It has been proven that variables related to its content, concept and outcome [39] have a predominant influence on the overall rating of a course [39]. Therefore, students' participation in research in the system of university science increases the quality of their assimilation of the taught courses and has a positive effect on their academic performance.

\section{Methods and Materials}

\subsection{Research design}

To achieve the goal and fulfill the objectives of the study, it was carried out in several stages. At the first stage, a range of problematic issues was identified, the object and subject of research were determined, its goal, objectives and hypothesis were formulated. At the second stage, the analysis of the regulatory framework for scientific, scientific-technical activities of universities was carried out, as well as the sources of scientific literature on this issue were analyzed. At the third stage, in order to experimentally study scientific and scientific-technical activities of the agrarian and economic universities of Russia, Kazakhstan, and Bulgaria, a special questionnaire was developed and a survey of a randomized sample of respondents was conducted. After that, statistical processing of the results of the questionnaire and their analysis were carried out. The features were highlighted and general patterns of scientific, 
scientific-technical activities of universities were identified, which made it possible to create a conceptual model of the development of university science. At the final stage of the study, conclusions were formulated and ways to optimize the systems of scientific, scientific-technical activities of higher educational institutions in the process of their reform were identified.

\subsection{Research methods}

To compare the current state of scientific and scientific-technical activities of universities in Russia, Kazakhstan, and Bulgaria, the authors took into account the regulatory documents regulating the activities of universities in these countries, and programs for the development of higher education, in particular:

- Federal Law No. 273-FZ dated December 29, 2012 "On education in the Russian Federation".

- Decree of December 26, 2017, No. 1642 "On approval of the State program of the Russian Federation for the development of education".

- Decree of the Government of the Republic of Kazakhstan dated August 9, 2012, No. 1037 "On approval of the Rules for the provision of innovative grants for the commercialization of technologies".

- Decree of the Government of the Republic of Kazakhstan dated June 20, 2011, No. 670 "On approval of the Norms of basic funding for scientific and/or scientifictechnical activities".

- Regulatory documents developed by the National Center for Scientific and Technical Information within the framework of the Program for the Development of the State System of Scientific and Technical Information of the Republic of Kazakhstan and the Program for the Modernization of Higher Education Systems in Europe.

In order to prevent systemic error and standardize the criteria for assessing the scientific, scientific-technical activities of universities in different countries and thereby ensure their comparison, the agro-economic universities were chosen as an industry that is one of the leading in all three countries. To obtain information from direct sources, a special questionnaire was developed on the basis of scientific literature data and aimed at a comprehensive subjective assessment of the scientific and scientifictechnical activities of universities by their employees.

The sample included 162 respondents, of which 52 - scientific and pedagogical employees of Sofia University (Bulgaria), 47 scientific and pedagogical employees of the Kazakh National Agrarian University of Almaty, as well as 63 representatives of the scientific and pedagogical personnel of higher educational institutions of Russia (24 respondents from Kuban State Agrarian University of Krasnodar, and 39 respondents from Plekhanov Russian University of Economics of Moscow). The was an anonymous online survey; the anonymity was ensured by assigning a certain code to each participant. A total of 240 questionnaires were sent out ( 80 for each country), of 
which 162 relevant answers were received. The research results were processed on medstatistic.ru.

\subsection{Limitations of the research}

The limitations of the study were due to the fact that a special questionnaire for studying scientific and scientific-technical activities of higher educational institutions was offered to respondents in English. Of the two possible options - to adapt the questions of the questionnaire to the languages of the respondents or to present them with a unified English-language text of the questionnaire - the second way was chosen. Although English is not a native language for any of the respondents, they all speak it sufficiently to understand the questionnaire and formulate appropriate answers. This created a level playing field for all study participants and simplified the processing of its results, and did not require additional time and money to translate the text of the questionnaire into several languages. The electronic distribution of the questionnaires made it possible to carry out the study in a short time, despite the fact that representatives of several countries participated in it.

As a limitation, one can consider conducting a study only among employees of agro-economic universities, which, on the one hand, makes it possible to identify specific features of their scientific, scientific-technical activities, and on the other hand, creates the problem of extrapolating the results obtained to universities in other industries. Nevertheless, the comparison of the current research results with the data of scientific literature made it possible to identify the main general laws of the development of university science and create an appropriate conceptual model on this basis. However, in order to confirm the correctness of the current conclusions, in the future, it is desirable to conduct similar studies in universities in other industries, which will clarify the created conceptual model, as well as reflect in it the features inherent in university science in various industries, which the authors plan to implement in the future.

\subsection{Ethical issues}

Ethical issues in this study are of particular importance as they relate, first of all, to the definition of the topic of scientific and scientific-technical research carried out in universities. The point is that a distinctive feature of modernity is that research carried out in higher educational institutions is financed, as a rule, by third-party investors, and the interests of a customer may not always correspond to bioethical norms, which often poses a difficult dilemma for university science: to develop the material and technical base by fulfilling orders that are questionable from an ethical point of view or curtail research due to lack of funding, waiting for better times. With due regard to the information above, it is needed to implement strict control over the principles of bioethics by the scientific community, as well as provide government subsidies to develop promising research areas and support scientific potential of universities.

In the course of the study, the systems of scientific and scientific-technical activities of higher educational institutions in different countries were studied without ref- 
erence to their ethno-specificity; the gender differences of the respondents were not considered as this was not part of the research objectives.

In the course of this study, the systems of scientific and scientific-technical activities of higher educational institutions in different countries were studied without reference to their ethno-specificity and the gender differences of the respondents.

\section{$4 \quad$ Results and Discussion}

When analyzing the systems of scientific and scientific-technical activities of agrarian and economic universities of Russia, Kazakhstan and Bulgaria, first of all, it is necessary to consider some features of national departments and organizations in the field of intellectual property of these countries, which indirectly reflect, in particular, the current state of the governance of scientific and scientific-technical activities of higher educational institutions as an integral system. It is the protection of intellectual property rights, as well as the rights to introduce the results of scientific-technical activities into economic circulation that is one of the essential components for ensuring the formation and effective operation of the national innovation system, which consists of higher educational institutions having powerful scientific and research potential. Considering that today the development of states directly depends on the intensification of innovation processes, and the leading role of higher educational institutions in their provision, there is a question related to the adequacy, effectiveness, and international standard conformity of the regulation of innovation activity, primarily legal protection and the protection of intellectual property. Thus, in the Republic of Kazakhstan, the leading institution in the field of scientific information is the National Institute of Intellectual Property of the Ministry of Justice of the Republic of Kazakhstan that subordinates to the Committee on Intellectual Property Rights of the Ministry of Justice and cooperates with the European Patent Office, the Eurasian Patent Organization for the acquisition of databases, as well as with the US Patent Office, which aims to maintain the level of inventiveness and popularize creative and intellectual activity. Today, the National System of Scientific and Technical Research of the Republic of Kazakhstan includes the National Center of Scientific and Technical Information of Kazakhstan with its subsidiaries as a parent organization. In particular, a large amount of scientific and technical information can be found in the libraries of higher educational institutions. A program aimed at the creation of an information environment favorable for the development of science is being implemented based on a systematic approach to the issues of information support for science and the scientific and technical sphere, as well as regular monitoring of the state of the scientific and technical potential of the Republic of Kazakhstan, including that concentrated in higher educational institutions. The importance of scientific support for large domestic manufacturers is emphasized at the state level, which opens up new opportunities for the introduction of innovations, ensuring economic growth, and increasing the role of science in the national economy. The development of university science is focused on the trilateral integration of education, science and industry, which is referred to as the "Golden Triangle" in the global practice. The tasks of high- 
er educational institutions include training of specialists and scientific personnel, the implementation of scientific research and scientific and industrial activities.

In the Russian Federation, the Federal Service for Intellectual Property, Patents and Trademarks, which is subordinate to the Ministry of Education and Science, keeps track of scientific innovations and regulates legal aspects. The priority tasks include a comprehensive solution to the issues of the creation and maintenance of a system ensuring the effective use of the potential of higher educational institutions, the implementation of the strategic priorities of a common university policy.

In Bulgaria, innovative development and industrial innovations are governed by the economy and energy sector, including the Advisory Council for Promotion of Small and Medium-sized Enterprises, which ensures effective interaction between the state administration, non-governmental organizations and commercial units [40]. The main organization for the development of decisions and their implementation within the Ministry of Economy and Energy is the Executive Agency for Small and Mediumsized Enterprises. The innovative development system is rationalized by the National Research Fund, whose funds are distributed on a competitive basis in three areas: national strategy and national programs; basic research; demonstration projects [40], but these have no discernible impact on science policy. In terms of innovativeness, Bulgaria ranks at the end of the list of European countries; there are few innovation networks being created, and universities and research institutions are not considered as a priority and relevant source of information and ideas for the development of new processes and products, which is a decisive factor in the modern global economy [4]. Despite the implementation of a number of important steps, national and international priorities in science have not been balanced. However, today in universities of Russia, Kazakhstan and Bulgaria, a lot of effort that is supported by the state and active international cooperation is being made to develop a system of scientific and scientifictechnical innovation. Table 1 describes the results of a comparative analysis of the subjective assessment of the involvement of universities of Russia, Bulgaria and Kazakhstan in scientific activities, obtained by the survey of the scientific and pedagogical personnel of these educational institutions. As can be seen from the table, the indicators of subjective assessment of scientific, scientific-technical activities of these universities show that each of them is rather concentrated on it. At the same time, there are some significant discrepancies in indicators that require further in-depth analysis and attention. 
Table 1. Comparative analysis of the subjective assessment of scientific and scientifictechnical activities of agrarian and economic universities in Russia, Bulgaria and Kazakhstan

\begin{tabular}{|c|c|c|c|c|c|c|c|}
\hline \multirow[b]{2}{*}{ No } & \multirow[t]{2}{*}{ Scientific activity indicators } & \multicolumn{2}{|c|}{ Russia } & \multicolumn{2}{|c|}{ Bulgaria } & \multicolumn{2}{|c|}{ Kazakhstan } \\
\hline & & \begin{tabular}{|l|}
$\begin{array}{l}\text { Absolute } \\
\text { number }\end{array}$ \\
\end{tabular} & $\%$ & \begin{tabular}{|l|} 
Absolute \\
number
\end{tabular} & $\%$ & $\begin{array}{l}\text { Absolute } \\
\text { number }\end{array}$ & $\%$ \\
\hline 1. & Promotion of scientific products & 32 & 50.8 & 18 & 34.6 & 41 & 78.8 \\
\hline 2. & $\begin{array}{l}\text { University achievements in the field of scientific } \\
\text { research, innovation, and promotion }\end{array}$ & 44 & 69.8 & 36 & 76.6 & 48 & 92.3 \\
\hline 3. & $\begin{array}{l}\text { Organizational support of scientific, scientific- } \\
\text { technical, and innovative activities of a universi- } \\
\text { ty }\end{array}$ & 28 & 44.4 & 25 & 53.2 & 33 & 63.5 \\
\hline 4. & $\begin{array}{l}\text { Monitoring and development of university re- } \\
\text { search activities }\end{array}$ & 26 & 41.3 & 22 & 46.8 & 39 & 75.0 \\
\hline 5. & Implementation of contract-based research & 21 & 33.3 & 16 & 34.0 & 46 & 88.5 \\
\hline 6. & $\begin{array}{l}\text { Implementation of joint scientific research and } \\
\text { scientific and industrial activities in cooperation } \\
\text { with research institutes and enterprises }\end{array}$ & 41 & 65.1 & 24 & 51.2 & 43 & 82.7 \\
\hline 7. & $\begin{array}{l}\text { Carrying out dissertation research (postgraduate, } \\
\text { doctoral programs) }\end{array}$ & 27 & 42.9 & 19 & 40.4 & 35 & 67.3 \\
\hline 8. & $\begin{array}{l}\text { Writing dissertations and master's theses based } \\
\text { on real projects }\end{array}$ & 46 & 73.0 & 29 & 61.7 & 44 & 84.6 \\
\hline 9. & Development of research centers and laboratories & 47 & 74.6 & 31 & 66.0 & 43 & 82.7 \\
\hline 10. & $\begin{array}{l}\text { Conducting scientific experiments in the research } \\
\text { laboratories of the university }\end{array}$ & 36 & 57.1 & 22 & 46.8 & 38 & 73.1 \\
\hline 11. & Expansion of cooperation with foreign partners & 52 & 82.5 & 45 & 95.7 & 48 & 92.3 \\
\hline 12. & $\begin{array}{l}\text { Organization of scientific and practical events } \\
\text { (conferences, webinars, etc.) }\end{array}$ & 62 & 98.4 & 44 & 93.6 & 50 & 96.2 \\
\hline 13. & Publications in scientometric databases & 39 & 61.9 & 41 & 87.2 & 42 & 80.8 \\
\hline 14. & Increasing the competency of the teaching staff & 51 & 81.0 & 45 & 95.7 & 49 & 94.2 \\
\hline 15. & Creation of scientific schools and centers & 44 & 69.8 & 27 & 57.4 & 34 & 65.4 \\
\hline 16. & $\begin{array}{l}\text { Participation in the solution of fundamental and } \\
\text { applied scientific problems }\end{array}$ & 33 & 52.4 & 24 & 51.1 & 46 & 88.5 \\
\hline 17. & Adequate funding & 23 & 36.5 & 19 & 40.4 & 31 & 59.6 \\
\hline 18. & Prestige of scientific career & 22 & 34.9 & 21 & 44.7 & 34 & 65.4 \\
\hline 19. & $\begin{array}{l}\text { Involvement of students in scientific activities } \\
\text { through scientific achievements in the learning } \\
\text { process }\end{array}$ & 56 & 88.9 & 34 & 72.3 & 48 & 92.3 \\
\hline 19.1 & Scientific student communities & 42 & 66.7 & 29 & 61.7 & 46 & 88.5 \\
\hline 19.2 & Competitions, student contests & 39 & 61.9 & 26 & 55.3 & 42 & 80.8 \\
\hline 19.3 & Conferences of young scientists & 52 & 82.5 & 31 & 66.0 & 48 & 92.3 \\
\hline 19.4 & Personal scholarships & 16 & 25.4 & 14 & 29.8 & 18 & 34.6 \\
\hline 19.5 & Student scientific community & 47 & 74.6 & 22 & 46.8 & 39 & 75.0 \\
\hline 19.6 & Council of young scientists & 42 & 66.7 & 18 & 38.3 & 32 & 61.5 \\
\hline 20. & $\begin{array}{l}\text { Job satisfaction, lack of professional burnout, } \\
\text { long-term plans and ideas }\end{array}$ & 39 & 61.9 & 31 & 66.0 & 44 & 84.6 \\
\hline TOT & & 63 & 100 & 47 & 100 & 52 & 100 \\
\hline $\mathrm{M}$ & & & 60.09 & & 60.88 & & 80.39 \\
\hline $\mathrm{Me}$ & & & 59.5 & & 56.4 & & 82.7 \\
\hline$\sigma$ & & & 18.89 & & 20.23 & & 11.39 \\
\hline $\mathrm{Cv}$ & & & 31.44 & & 33.24 & & 14.17 \\
\hline $\mathrm{m}$ & & & 4.33 & & 4.64 & & 2.61 \\
\hline
\end{tabular}


This table presents the questions of the questionnaire and the number of respondents for each of the three countries, in total and in percentage, as well as indicators of statistical online processing of the results obtained.

First of all, it should be noted that the indicators of scientific and scientifictechnical activities of agrarian and economic universities in Russia and Bulgaria are comparable and differ insignificantly while being much higher in Kazakhstan. When analyzing the results obtained, one should take into account that the study involved those higher educational institutions whose activities relate mainly to the agricultural industry and the trade and economic sphere, and they are the leading educational and scientific centers in the countries discussed. Moreover, the educational process at Plekhanov Russian University of Economics as confirmed by the results of the research, is highly practice-oriented and consistent with the realities of the economic situation both in the country and in the international arena, and the scientific school of the university forms the basis for the academic economic community of Russia. The advantages of the scientific activity of this university are, primarily, the opportunity to write dissertations for a scientific degree and master's theses based on real material, a close connection between science and practice, the implementation of joint scientific and scientific-technical research projects in cooperation with specialized research institutes and enterprises, including foreign ones. The availability of a developed network of research laboratories allows carrying out fundamental and applied research. However, the comparison of the average indicators of the subjective assessment of the scientific and scientific-technical activities of Russian, Bulgarian and Kazakhstan agricultural and economic universities shows that the Kazakh National Agrarian University ranks first among studied higher educational institutions. This is a predictable result as the university is leading the way in Kazakhstan agriculture carrying out the scientific and educational process at the level of international standards and in cooperation with the real sector of the economy, thereby ensuring the high competitiveness of graduates both on the national and global labor markets. Successful implementation of innovative activities based on the integration of education, science and production in the agro-industrial complex of Kazakhstan ensured the entry of the Kazakh National Agrarian University into the top 300 universities according to the QS World University Ranking, which assesses universities by six indicators: research activity, teaching, employers' opinion and career potential, number of foreign students and teachers.

Compared to Bulgaria, the results of the subjective assessment of the scientific and scientific-technical activities of Russian universities have confirmed the focus on the creation of scientific schools, the implementation of dissertation research, and the availability of research laboratories. However, it should be noted that these are past developments, and the current situation demonstrates poor research development rates, first of all, in terms of stable and adequate funding. One cannot say that innovative activity in Russian universities is not a priority - on the contrary, great attention is paid to the organization of research and innovative activities of both teachers and students; highly qualified teaching staff are involved in the process; innovative educational programs are developed and implemented, including double and triple degree programs in cooperation with leading foreign universities. Plekhanov Russian Univer- 
sity of Economics is also listed in the QS World University Ranking and other regional and international rankings, where it is positioned close to the top. We cannot state that the lag is associated with disregard for university science; it is more likely related to the fact that in recent years many universities in other countries have realized its priority as the basis for both competitiveness and international prestige, and the results of our research indicate the priority of the development of science and all kinds of support for innovative scientific research at the state level. Promotion of innovations, organizational and financial support for scientific, scientific-technical, and innovative activities, improvement of the competencies of the teaching staff are the priority areas in Bulgaria, which until recently demonstrated one of the lowest innovative activity indicators in the world [4]. The adoption of scientific research at Sofia University as a strategic development goal based on the principles of effective interaction between the educational process, science, technological development, and innovation policy supported by various sources of funding, including national and European programs, national institutions, non-governmental organizations, etc., ensures positive results allowing the university to compete with foreign educational institutions, catch up with their level, as well as surpass their performance. We should also highlight the problems identified by the research participants, such as unstable funding and a decline in the prestige of the scientific career, which complicates the attraction of young people to science, leads to the aging of scientific personnel, and often causes job dissatisfaction and the risk of professional burnout. Even though there is state support, university science is experiencing financial and personnel difficulties, which is a global problem and, in the context of fierce competition, creates increased requirements for the quality of scientific products of higher educational institutions and their promotion in the market of research and scientific-pedagogical services.

According to the research (presented in literature data) of innovation activity of enterprises in the European Union (Community Innovation Survey), one third of European enterprises are innovative [4]. The innovative leaders are Slovenia, Great Britain, Germany, and Cyprus while most post-Soviet countries, in particular Latvia, Lithuania, Poland, Romania, Hungary, and Bulgaria, are at the bottom of the ranking [4]. This study is conducted only in EU member states and it does not include indicators of innovative activities of Russia and Kazakhstan. Nevertheless, it can be assumed that in these countries the level of innovative activity is comparable to the indicators of other countries of the post-Soviet space and does not fully correspond to the pace of development of European economies [4]. Considering that the innovative development of enterprises directly depends on the level of education and the contribution of scientific and scientific-technical activities of universities, the results of our research reflect not only the current state of university science in a comparative aspect, but also allow us to indirectly assess the parameters of the "knowledge triangle" - a trilateral relationship between education, science and business, which makes it possible to predict the prospects for the economic development of countries. It was interesting to compare the scientific and scientific-technical activities of universities in different countries of the post-Soviet space, but the same agro-economic direction, which, having much in common in terms of sectoral affiliation and organizational aspects of scientific activity, and valuable historical experience in the establishment of 
fundamental scientific schools, are restructuring their activities in accordance with modern requirements of innovation. While the majority of prior studies considered objective statistical indicators of the innovative activity of higher educational institutions, the present paper examines the subjective assessment of the process, i.e. the scientific and pedagogical personnel of higher educational institutions assesses the involvement of their universities in the innovative activity linking fundamental and applied university science with practice and economic benefits. The possibility to determine the real state and direction of the development of university science through the subjective expert assessment can be considered as an important advantage of the selected research methodology; at the same time, online research has some disadvantages associated with the lack of direct communication and an emotional component, which could distort the research results to a certain extent.

Comparative analysis shows that among the three studied countries, the University of Kazakhstan occupies a leading position in terms of scientific, scientific-technical research, primarily in relation to promoting scientific products, university's achievements in innovation field and monitoring research activities for further development. The universities of Bulgaria and Russia are inferior to Kazakhstan in these positions and, in addition, Bulgaria is ahead of Russia in the field of organizational support for scientific, scientific-technical innovation. The Russian universities occupy leading positions in the creation of scientific schools and centers, and also have good indicators in relation to research centers and laboratories, however, perhaps this priority is associated not so much with the current development of the material and technical research base of universities, but with the legacy of the Soviet period. Closer examination of this item of the questionnaire may show that this research base is largely outdated and in need of modernization. This is indirectly evidenced by the fact that Kazakhstan is noticeably ahead of Russia in terms of conducting scientific experiments in university laboratories related to this item of the questionnaire. Bulgaria is inferior to both Kazakhstan and Russia in terms of performing scientific work based on real projects, but it comes out on top in cooperation with foreign partners. Bulgaria as other two countries holds scientific and practical conferences and is the undisputed leader in terms of the number of publications while the universities of Russia show a significant lag in this item of the questionnaire.

Attention is drawn to the confident leadership of Kazakhstan universities in terms of participation in solving fundamental and applied scientific problems. In addition, high indicators in relation to attracting students to scientific work, the use of scientific achievements in the learning process, the organization of olympiads and conferences of young scientists clearly indicate the significant attention of both university and state educational policies of Kazakhstan to attracting young people in the scientific sphere. The latter is a far-sighted step in ensuring the future development of science as a guarantee of the welfare of the state as a whole. This is ensured, first of all, by adequate funding of scientific, scientific-technical research, and although on this point in all the universities studied, the indicators are not very high, however, Kazakhstan universities differ in much better indicators on this point, both in comparison with Bulgaria and especially with Russia. Accordingly, the significant attention of the educational policy of Kazakhstan to the development of university science is reflected 
in the much higher prestige of the scientific profession in this country, in comparison with the indicators of Bulgaria and Russia. At the same time, in Bulgaria the activation of state policy in the field of support of scientific, scientific-technical research led to the intensification of the process of overcoming the crisis tendencies of the postSoviet period by university science. In Russia, there is some inertia, which makes it necessary to revise the priorities of educational policy and its target orientation towards development of scientific, scientific-technical activities of universities. The survey results reflect, first of all, the situation in the field of scientific, scientifictechnical activities of universities in the agricultural and economic sector, but they also correspond to the problems of university science that are described by other researchers and analyzed in the literature review, since these problems are of a global nature. Based on the foregoing, scientific, scientific-technical activities of agrarian and economic universities of Russia, Kazakhstan, and Bulgaria were compared with the data of scientific literature. A generalized conceptual model of the system of scientific, scientific-technical activities of universities was created (Fig. 3).

Generally, the modern system of university science can be schematically described as a conceptual model with a focus on the key blocks that make up the major components and priority areas (Fig. 3).

The first and most important block is the comprehensive support for scientific research. Each block component is an important link that ensures the development of scientific and scientific-technical activities of a higher educational institution. The development of university science as a strategic state policy direction should be based on the analysis of the economic situation and the market for science-intensive technologies and intellectual services and described in regulatory documents. In addition, it is necessary to ensure intellectual property protection and copyright, which also requires legislative support. We should highlight the issue of research funding which not only determines the focus of scientific research but also ensures the observance of the basic principles of bioethics and academic integrity during the course of the study.

Today, international cooperation, which is based primarily on joint innovation projects, is of particular importance as it is the integration of research activities from different countries that can provide conditions for obtaining a high-quality innovative scientific product. In addition, an important component of international cooperation of higher educational institutions in the field of science is the exchange of students and foreign training of scientific and pedagogical personnel. The publication of scientific research in journals indexed in scientometric databases, first of all, in SCOPUS and Web of Science, can be considered as an option for international cooperation, the importance of which is difficult to overestimate. Unfortunately, this is a serious challenge faced by a number of scientists as, firstly, the topics of publications do not always correspond to the subject area of indexed journals, and secondly, the publications fail to achieve the required quality level. Nevertheless, the need to comply with the international standards of scientific work is an effective stimulus for development and attracts young scientists through prosperous development opportunities. 


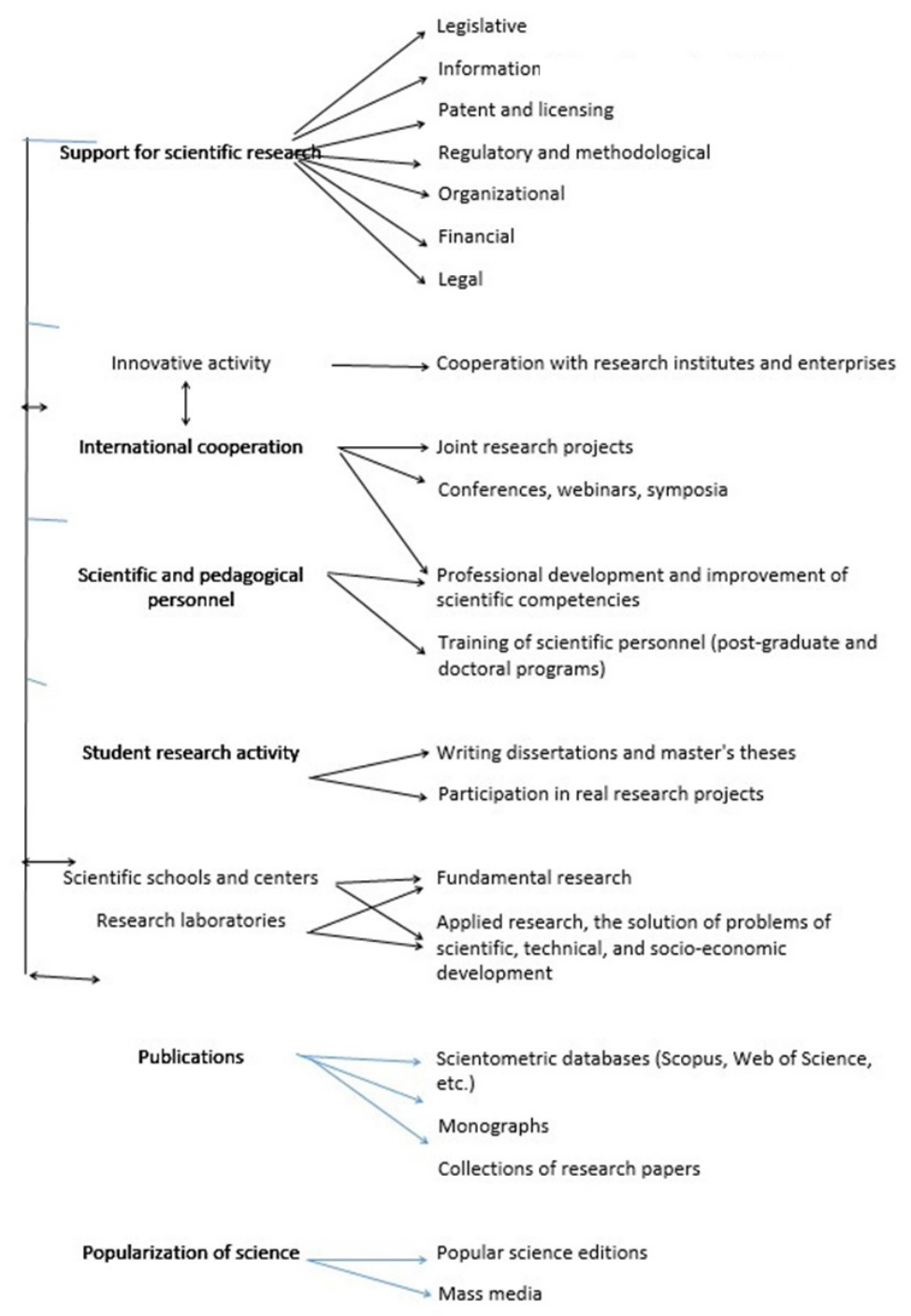

Fig. 3. Conceptual model of the system of scientific and scientific-technical activities of universities

The presented conceptual model schematically describes the system of scientific and scientific-technical activities of higher educational institutions; however, the generalized model cannot reflect the complexity and multitasking nature of the system - each system element is an important component of an integral structure providing a single mechanism for achieving high quality scientific products of higher educational institutions. 


\section{Conclusion}

As a result of the study, the general and distinctive characteristics of scientific and scientific-technical activities of the agrarian and economic universities of Russia, Kazakhstan, and Bulgaria were identified. Based on this, in comparison with the data of scientific literature, a generalized, universal conceptual model of scientific, scientific-technical activities of universities aimed at optimizing the process of reforming university science and developing the research potential of higher educational institutions was created.

The analysis of scientific literature sources on the research topic allowed concluding that scientific, scientific-technical activities of universities in the highly competitive environment of the modern market of educational services are becoming the priority area. The development of the scientific potential of universities is interconnected with the professional development of teachers, their self-efficacy and job satisfaction. Problems and risks, such as instability of economic processes, the outflow of young people and highly qualified personnel abroad or to higher-paid sectors of the economy, a decline in the prestige of scientific and scientific-pedagogical activities necessitate monitoring the efficiency of scientific activities of universities to optimize university science management.

The results of the research indicate that significant work has been carried out to reform the innovative activities of agrarian and economic universities in Russia, Kazakhstan, and Bulgaria, aimed at ensuring compliance of legal protection and protection of intellectual property with international standards. This vector of development of scientific, scientific-technical activities of these universities corresponds to current global trends related to the protection of intellectual property, the rights to the results of scientific and technical activities.

The results of the study of subjective assessment of scientific activity of agrarian and economic universities of Russia, Kazakhstan, and Bulgaria indicate that in each of them, scientific research is given sufficient attention. Nevertheless, a comparison of the subjective assessment of scientific, scientific-technical activities of the agrarian and economic universities of Russia with those of Bulgaria and Kazakhstan shows that the Kazakh National Agrarian University is a leader. This is a completely logical result, since this university is the leader of the agrarian sector of Kazakhstan, carrying out the scientific and educational process at the level of international standards and in interaction with the real sector of the economy, and thereby ensuring the high competitiveness of graduates both on the national and world labor markets. These successes in ensuring innovative activities based on the integration of education, science, and production in the agro-industrial complex of Kazakhstan ensured the entry of the Kazakh National Agrarian University into 300-universities world ranking of the QS agency. The latter evaluates universities according to six indicators: research activity, teaching, employers' opinion and career potential, the number of foreign students and teachers. The results of the subjective assessment of scientific, scientific-technical activities of this university in comparison with similar indicators of the agrarian and economic universities of Russia and Bulgaria, confirm the high level of innovative 
development of university science, which is largely ensured by the priority of the vectors of educational state policy of Kazakhstan in this direction.

The results of the subjective assessment of scientific, scientific-technical activities of the agrarian and economic universities of Russia testify to the priority in the creation of scientific schools, the conduct of research, the presence of research laboratories compared with the analogous indicators of university science in Bulgaria. However, this result is largely based on the developments of the past years, while the current situation shows an insufficient rate of development of the research base, primarily in terms of stable and sufficient funding. At the same time, much attention is paid to the organization of research and innovation work of teachers and students, highly qualified teaching staff is involved in the work, innovative educational programs are developed and implemented, including double and triple degree programs with leading foreign universities.

The results of the research indicate the priority of the development of science and significant support for innovative scientific research in Bulgaria at the state level, which contributes to an increase in the prestige and competitiveness of Bulgarian university science.

As the results of the study show, global problems of the system of scientific, scientific-technical research in universities are unstable funding and a decline in the prestige of a scientific career, which make it difficult to attract young people to science, lead to aging of scientific personnel, dissatisfaction with work and risk of professional burnout. The conditions of tough competition place increased demand on the quality of scientific products of universities and their promotion in the market of research and scientific and pedagogical services. An analysis of the positive indicators of the development of university science on the example of agricultural and economic universities in Bulgaria and Kazakhstan indicates the need to support scientific, scientifictechnical activities of universities at the state level, the formation of targeted educational policy and its adequate funding.

Thus, today universities should give priority attention to the field of science, clearly define strategic goals and constantly update and improve the research base, develop innovative activities based on the close relationship of theory and practice, fundamental and applied research, in partnership with enterprises representing the leading sectors of the state economy. At the same time, a feature of the global modern world is the integration of scientific, scientific-technical activities of individual universities into the international scientific space. The latter provides new opportunities for research, development of human resources, mastery of new high technologies, and exacerbates the problem of compliance with bioethical norms and academic decency, scientific resource management and intellectual property protection at all levels. In addition, as confirmed by the research, the key to the successful development of university science and its competitiveness on a global scale is a purposeful innovative educational policy of the state that supports scientific, scientific-technical activities of universities. 


\section{$6 \quad$ References}

[1] ITMO University (2020). ITMO University: Scientific activity of the university.https://itmo.ru/ru/stat/106/4. nauchnaya deyatelnost vuza.htm/.https://doi.org/ 10.17586/1606-4313-2020-19-2-52-59

[2] Shynyaeva, O.V., Akmanaeva, D. Kh. (2011). The role of students' scientific activity in improving the functionality of Russian higher education. News of higher educational institutions. Volga region. Social Sciences, 4(20): 60-71.

[3] Federal Service for Supervision in the Sphere of Education and Science (2006). Expert assessment of the conduct, organization and results of research activities at the university. Methodological guidelines. National Institute of Business, Moscow.

[4] Damianova, L.T. (2015). Innovation activities in Bulgaria: state and prospects. Russian Journal of Innovation Economic, 5(3): 141-158.

[5] Roberts-Mahoney, H., Means, A.J., Garrison, M.J. (2016). Netflixing human capital development: Personalized learning technology and the corporatization of K-12 education. Journal of Education Policy, 31: 405-420. https://doi.org/10.1080/02680939.2015.1132774

[6] Safari, I., Davaribina, M., Khoshnevis, I. (2020). The Influence of EFL Teachers' SelfEfficacy, Job Satisfaction and Reflective Thinking on Their Professional Development: A Structural Equation Modeling. Journal on Efficiency and Responsibility in Education and Science, 13(1): 27-40. https://doi.org/10.7160/eriesj.2020.130103

[7] Brighouse, H., Ladd, H.F., Loeb, S., Swift, A. (2018). Educational goods: Values, evidence, and decision making. University of Chicago Press, Chicago, IL.https://doi.org/ 10.7208/chicago/9780226514208.001.0001

[8] Belarus National Information Point For EU Research And Innovation Programmes (2020). About Horizon 2020 program. http://fp7-nip.org.by/ru/hor20/about/

[9] Regele, M.D. (2020). Pedagogy and Profit? Efforts to Develop and Sell Digital Courseware Products for Higher Education. American Educational Research Journal, 57(3): 1125-1158.https://doi.org/10.3102/0002831219869234

[10] Sivolobova, N. (2011). The role of educational fundraising in the innovative activities of universities. Problems of training a modern teacher, 3: 124-130.

[11] Poltorak, S.T. (2017). Prospects for the development of public administration of the system of higher education of Ukraine. Bulletin of NUCDU (Series "Public Administration"), 2(7): 214-220.

[12] Gonnova, S.M., Razuvaeva, E.Y. (2019). National Systems of Scientific and Technical Information Have Potential for the Development of Scientific Diplomacy in the CIS. Scientific and Technical Information Processing, 46(4): 261-279.https://doi.org/10.3103/ s0147688219040105

[13] Tsvetkova, M., Suleimenov, Z., Kondratenko, L., Stepanova, D. (2020). Formation and Development of the Scientific and ScientificTechnical Activity Systems at Universities. Talent Development \& Excellence, 12(1): 3261-3275.

[14] Lappalainen, P.H. (2018). Tracing Pedagogical Progression on the Doctoral Level. International Journal of Engineering Pedagogy, 8(5):58-73.

[15] Simonics, I. (2020). Relationships among Economy, Industry, Vocational Education and Training and Higher Engineering Education - The Trefort Project Editorial. International Journal of Engineering Pedagogy, 10(5): 4-6. https://doi.org/10.3991/ijep.v10i5. 16747

[16] Ferro, G., D'Elia, V. (2020). Higher Education Efficiency Frontier Analysis: A Review of Variables to Consider. Journal on Efficiency and Responsibility in Education and Science, 13(3): 140-153. https://doi.org/10.7160/eriesj.2020.130304

[17] Kuzmin, O., Melnyk, O., Zhuk, L. (2018). Formation of diagnostics indicator base of the university scientific activity system: Economics and Management of Enterprise. Technol- 
ogy Audit and Production Reserves, 1(4): 9-15. https://doi.org/10.15587/2312$\underline{8372.2018 .124396}$

[18] Penuel, W.R., Riedy, R., Barber, M.S., Peurach, D.J., LeBouef, W.A., Clark, T. (2020). Principles of collaborative education research with stakeholders: Toward requirements for a new research and development infrastructure. Review of Educational Research, 90(5): 627-674. https://doi.org/10.3102/0034654320938126

[19] Greene, J.A., Lobczowski, N.G., Freed, R., Cartiff, B.M., Demetriou, C., Panter, A.T. (2020). Effects of a Science of Learning Course on College Students' Learning with a Computer. American Educational Research Journal, 57(3): 947-978. https://doi.org/10. $3102 / 0002831219865221$

[20] Joyce, K.E. (2019). The key role of representativeness in evidence-based education. Educational Research and Evaluation, 25(1-2): 43-62.20

[21] Joyce, K.E., Cartwright, N. (2020). Bridging the gap between research and practice: Predicting what will work locally. American Educational Research Journal, 57(3): 1045-1082. https://doi.org/10.3102/0002831219866687

[22] Bridges, D. (2017) Educational Research and Philosophy in 'Interesting Times'. In Philosophy in Educational Research. Springer, Cham, pp. 1-10. https://doi.org/10.1007/ 978-3-319-49212-4 1

[23] Coburn, C.E., Penuel, W.R. (2016). Research-practice partnerships in education: Outcomes, dynamics, and open questions. Educational Researcher, 45: 48-54. https://doi.org/10.3102/0013189x16631750

[24] Kvernbekk, T. (2016). Evidence-based practice in education: Functions of evidence and causal presuppositions. Routledge, New York, NY. https://doi.org/10.4324/9780203774 $\underline{830}$

[25] Savelsbergh, E.R., Prins, G.T., Rietbergen, C., Fechner, S., Vaessen, B.E., Draijer, J.M., Bakker, A. (2019). Corrigendum to Effects of Innovative Science and Mathematics Teaching on Student Attitudes and Achievement: A Meta-Analytic Study. Educational Research Review, 19: 158-172. https://doi.org/10.1016/j.edurev.2019.02.002

[26] Van Beveren, L., Roets, G., Buysse, A., Rutten, K. (2018). We all reflect, but why? A systematic review of the purposes of reflection in higher education in social and behavioral sciences. Educational Research Review, 24: 1-9.https://doi.org/10.1016/j.edurev. 2018.01.002

[27] Shaban, K., Abdulwahed, M., Younes, A. (2015). Problem-centric process for researchbased learning. International Journal of Engineering Pedagogy, 5(2): 24-30. https://doi.org/10.3991/ijep.v5i2.4506

[28] Kryshtal, D.O. (2018). Organizational Mechanism of Public Regulation of Scientific and Technical Activity of Higher Education Institutions. East Journal of Security Studies, 1(3): $1-10$.

[29] Nikiforov, A.A., Utkin, L.V. (2010). Rating assessment and monitoring of the educational and scientific activity of university. University Management: Practice and Analysis, 3: 5461.

[30] Makhov, A.A. (2000). Social problems of the development of scientific and technical creativity of students in the system of engineering education. Abstract of the candidate of sociological sciences thesis.

[31] Groove, J. (2011). Triple miracle' sees hude rise in EU funds for frontier research, Times Higher Education. https://www.timeshighereducation.com/news/triple-miracle-sees-hugerise-in-eu-funds-for-frontier research/416952. article?storycode $=416952$

[32] AWS (2020). A series of webinars for leaders in higher education. Digital Information in Higher Education. https://pages.awscloud.com/webinar-digital-innovation-highereducation.html?trk=wwps-emea-edu-web-series-oct-2020-timespromo\&utm_source=Dig ital\%20ads\&utm medium=Digital\%20ads\&utm_campaign=Digital\%20ads\%20THE. https://doi.org/10.4337/9781788970167.00012 
[33] Economic Council of the Commonwealth of Independent States (2010). Decision of the Economic Council of the Commonwealth of Independent States on the state of national systems of scientific and technical information in the CIS member states.https://zakon.rada.gov.ua/laws/show/997_m63\#Text. https://doi.org/10.18356/e345a bf5-en

[34] Stelios, S., Christodoulou, A. (2020). Teaching Professional Integrity: An Empirical Study on Engineering Students. International Journal of Engineering Pedagogy, 10(3): 98-105. https://doi.org/10.3991/ijep.v10i3.12013

[35] Yoon, I. (2020). Developing a Course to Choose an Engineering Major at Colleges with a Pre-Engineering Program Only. International Journal of Engineering Pedagogy, 10(4): 6992. https://doi.org/10.3991/ijep.v10i4.12987

[36] Santos, L.B., Xavier, P.H.F., Santos, J.V.C., Sampaio, R.R. (2020). Teaching of Ordinary Differential Equations Using the Assumptions of the PBL Method. International Journal of Engineering Pedagogy, 10(3): 7-20. https://doi.org/10.3991/ijep.v10i3.12015

[37] Jacques, S., Lequeu, T. (2020). The Attractiveness of Reversing Teaching FormsFeedback on an Electrical Engineering Course. International Journal of Engineering Pedagogy, 10(3): 21-34. https://doi.org/10.3991/ijep.v10i3.12361

[38] Jarkovská, P., Jarkovská, M. (2020). A Contemporary Approach to Managing Social Responsibility in Relation to Employees as Perceived in Academic Papers. Journal on Efficiency and Responsibility in Education and Science, 13(3): 101-112. https://doi.org/10.7160/eriesj.2020.130301

[39] Faichikova, A., Feifarova, M. (2019). Evaluation of the Quality of Teaching from the Perspective of University Students. Journal on Efficiency and Responsibility in Education and Science, 12(2): 34-40.

[40] Simeonova, K. (2006). Research and innovation in Bulgaria. Science and Public Policy, 33(5): $351-363$.

\section{$7 \quad$ Authors}

Tsvetkova Milena Ivanova is a Doctor, Associate Professor of the Faculty of Journalism and Mass Communication, Sofia University, Sofia, Bulgaria. Email: tsvetkovamile@,rambler.ru

Suleimenov Zhenisbek Zhumagalievich is a Doctor of Economic Sciences, Director of the Institute of Agribusiness and Consulting, Department of Management and Organization of Agribusiness, Kazakh National Agrarian University, Almaty, Kazakhstan.

Kondratenko Larisa Nikolaevna is a $\mathrm{PhD}$ of Technical Sciences, Associate Professor of the Department of Advanced Mathematics, Kuban State Agrarian University I. T. Trubilin, Krasnodar, Russia.

Stepanova Diana Igorevna is a $\mathrm{PhD}$, Associate Professor of the Department of Finance and Prices, Plekhanov Russian University of Economics, Moscow, Russia.

Article submitted 2020-12-15. Resubmitted 2021-02-02. Final acceptance 2021-02-02. Final version published as submitted by the authors. 